\title{
Responses of cloned rainbow trout Oncorhynchus mykiss to an attenuated strain of infectious hematopoietic necrosis virus
}

\author{
Sandra S. Ristow ${ }^{1, *}$, Scott E. LaPatra ${ }^{2}$, Richard Dixon ${ }^{1}$, Christine R. Pedrow ${ }^{1}$, \\ William D. Shewmaker ${ }^{2}$, Jeong-Woo Park ${ }^{3}$, Gary H. Thorgaard ${ }^{4}$ \\ ${ }^{1}$ Washington State University, Department of Animal Science, 114 New Experimental Animal Laboratory Building, \\ Pullman, Washington 99164-6351, USA \\ ${ }^{2}$ Clear Springs Foods, Buhl, Idaho 83316, USA \\ ${ }^{3}$ Department of Microbiology, University of Ulsan, Ulsan 680-749, Korea \\ ${ }^{4}$ School of Biological Sciences, Washington State University, Pullman, Washington 99164-4236, USA
}

\begin{abstract}
The objective of this work was to examine the response of homozygous clones of rainbow trout to vaccination by an attenuated strain (Nan Scott Lake; NSL) of infectious hematopoietic necrosis virus (IHNV). Adult rainbow trout of the Hot Creek Strain (YY males maintained in a recirculating system at $12^{\circ} \mathrm{C}$ ) were injected 3 times with $10^{5}$ to $10^{7}$ plaque forming units (pfu) of NSL. Intraperitoneal injections were given at Day 0 and at 2 and 4 mo post-infection. All fish were nonlethally bled at monthly intervals for 18 mo. Serum from each fish was analyzed by the complementdependent neutralization assay and by western blot against purified NSL virus. The highest virus neutralization titers were detected 4 mo after the first injection, and peaked at 1280 . When sera were analyzed by western blot, the predominating responses of the serum from immunized fish on the reduced western blot were against M1, a matrix protein of the virus and to a $90 \mathrm{kDa}$ stress protein. The $90 \mathrm{kDa}$ protein was identified by a monoclonal antibody as a stress protein derived from the CHSE-214 cells in which the purified IHN virus was grown and which associates with the virus during purification.
\end{abstract}

KEY WORDS: IHNV · Vaccine $\cdot$ Homozygous clones $\cdot$ Rainbow trout $\cdot$ Immunity

Resale or republication not permitted without written consent of the publisher

\section{INTRODUCTION}

Infectious hematopoietic necrosis virus (IHNV) is an important viral pathogen of rainbow trout Oncorhynchus mykiss. Each year, infections caused by IHNV economically impact commercial and resource management aquaculture. Significant time and effort has been expended in producing experimental vaccines to minimize the effect of IHNV. Among the current successful vaccines for this pathogen are a DNA vaccine (Anderson et al. 1996a,b), the betapropiolactone in-

*E-mail: ristow@wsu.edu activated IHNV vaccine (Amend et al. 1976) and an attenuated strain of IHNV (Leong et al. 1988).

Work leading to optimization of effective vaccines is still underway and includes efforts to understand the immune system of the trout, to study various biological response modifiers which promote beneficial immune responses and to elucidate routes of antigen presentation in these fish. Engelking \& Leong (1989) showed that the immunization of rainbow trout with the outer coat glycoprotein (G) of IHNV produced a protective response against the virus. They also showed that there appears to be a single serotype of this virus since an immunization with $\mathrm{G}$ protein from a single isolate can induce the production of neutralizing antibodies in 
fish, mice and rabbits that cross-react with all strains (Engelking et al. 1991). Several other workers later began to examine the responses of outbred rainbow trout to individual proteins of IHNV (LaPatra et al. 1993, Ristow et al. 1993) and to various epitopes present on the G protein (Mourich \& Leong 1991, Emmenegger et al. 1997). There is now an effort to look in greater depth at the mechanisms of antigen presentation in trout, and in this paper, we examine the serological responses of cloned rainbow trout to a strain of attenuated IHNV.

One of our laboratories has produced isogenic lines of rainbow trout by androgenesis, a method of reproduction in which irradiated eggs fertilized by normal spermatozoa result in progeny with total paternal inheritance (Parsons \& Thorgaard 1985, Scheerer et al. 1986, 1991, Young et al. 1996). In addition, inbred lines can also be produced with all maternal inheritance by gynogenesis, a process in which viable eggs are fertilized by irradiated spermatozoa (Quillet et al. 1991). Individuals within the clones of rainbow trout produced by our laboratories have been shown to be homozygous by restriction fragment length polymorphism (RFLP) analysis (Young et al. 1996) and cell lines derived from each line have RFLPs identical to the parental fish (Ristow et al. 1998). We have been characterizing these homozygous clones of trout as subjects for fish disease research and as lower vertebrate biomedical models. Thusfar, we have elucidated nonspecific cytotoxic cell activity patterns (Ristow et al. 1995) and have begun work on the sequencing of the major histocompatibility antigens of these cloned fish (Ristow et al. 1999).

The objectives of the present work were to evaluate the serological responses of cloned rainbow trout to a known successful attenuated vaccine (Leong et al. 1988). The subsequent humoral response of the cloned trout was then followed with a complement-dependent neutralization technique and by western blot over an $18 \mathrm{mo}$ period. The results were analyzed to determine the similarity of responses amongst the cloned individuals.

\section{MATERIALS AND METHODS}

Fish. The Hot Creek strain of rainbow trout was obtained from the Hot Creek Hatchery operated by California Fish and Game. The homozygous line was produced by 2 rounds of androgenesis. Androgenesis was accomplished by fertilizing gamma-irradiated eggs with normal sperm. In this procedure, eggs were first irradiated with a ${ }^{60} \mathrm{Co}$ source to a final dose of $3 \times$ $10^{4}$ rads, after which they were fertilized by normal sperm (Parsons \& Thorgaard 1985). Homozygous diploid trout were produced by heat or pressure shock, blocking the first cleavage; therefore, both chromo- some sets were derived from the male parent (Parsons \& Thorgaard 1985, Scheerer et al. 1991). Fish used in the present experiments were $2 \mathrm{yr}$ old $1000 \mathrm{~g}$ YY males of the Hot Creek (HC) strain kept in a recirculating system at $12^{\circ} \mathrm{C}$. All fish were individually tagged for identification purposes.

Preparation of virus. The $100 \times$ pass Nan Scott Lake Virus (NSL), prepared by multiple passages in tissue culture (Leong et al. 1988), was inoculated at a multiplicity of infection of 0.1 plaque forming units (pfu) per cell into CHSE-214 cells. The infection was allowed to proceed for $14 \mathrm{~d}$ and the supernatant was harvested by centrifugation. To purify the virus, supernatants were subjected to a series of centrifugations over buffered sucroses as described in detail by Leong et al. (1981).

Immunization with virus. On Day 0, fish were anesthetized in a $0.04 \%$ solution of 2-phenoxyethanol and were intraperitoneally injected with $1 \times 10^{5}$ pfu of virus. Two months later they were injected with $1 \times 10^{7} \mathrm{pfu}$ and subsequently at 4 mo they were injected with $2 \times$ $10^{7} \mathrm{pfu}$.

Serum. Fish were anesthetized as described above at monthly intervals and $1.5 \mathrm{ml}$ of blood was withdrawn by heart puncture. Blood was allowed to clot overnight at $4^{\circ} \mathrm{C}$ and the serum separated by centrifugation at $550 \times g$ (Ristow et al. 1993). Virus neutralizing activity in the serum was analyzed using the complementdependent plaque neutralization assay (LaPatra et al. 1993, Ristow et al. 1993). Samples were heat-inactivated $\left(45^{\circ} \mathrm{C}\right.$ for $\left.30 \mathrm{~min}\right)$ to destroy residual complement and 2 -fold dilutions of the serum made. An equal volume of diluted virus (isolate 220-90; LaPatra et al. 1991) was added to each well and plates were incubated for $30 \mathrm{~min}$ on a rocker platform at $18^{\circ} \mathrm{C}$. Rainbow trout complement from a quality controlled standard source (LaPatra et al. 1996) was added at a dilution of 1:10. Samples were inoculated onto polyethylene glycol treated monolayers of epithelioma papulosum cyprini (EPC) cells (Fijan et al. 1983) grown in 48-well plates, rocked at $18^{\circ} \mathrm{C}$ for $1 \mathrm{~h}$ to permit adsorption of the virus and overlayed with methyl cellulose. After incubation for $6 \mathrm{~d}$ at $17^{\circ} \mathrm{C}$ the monolayers were stained with a crystal violet/formalin solution. Neutralization titers were determined by noting the reciprocal of the serum dilution resulting in a $50 \%$ reduction in the average number of plaques compared to the negative controls.

Western blots. Western blots were performed by electrophoresing $100 \mu \mathrm{g}$ of purified NSL virus in Laemmli buffer in the preparative well of preformed, 4 to $15 \%$ gradient gels (BioRad \#161-1140) under reduced conditions in a BioRad Ready Gel ${ }^{\mathrm{TM}}$ Cell. Proteins of the virus and molecular weight standards (Kaleidoscope ${ }^{\mathrm{TM}}$, BioRad \#161-0324) were transferred to nitrocellulose in $25 \mathrm{mM}$ Tris, $192 \mathrm{mM}$ glycine $10 \% \mathrm{v} / \mathrm{v}$ methanol, $\mathrm{pH}=8.3$ for $60 \mathrm{~min}$ at $100 \mathrm{~V}$. The blots were 
blocked with $5 \%$ milk/Tris buffered saline with $0.1 \%$ Tween 20 (TBST) and washed 3 times in TBST. Dilutions $(1: 10)$ of the individual sera were made (in $5 \%$ milk/TBST) and the blot sandwiched into the BioRad MiniPro Multiscreen. Dilutions of the various trout sera were injected into the wells of the device. The sera were applied to the blot for $16 \mathrm{~h}$ at $16^{\circ} \mathrm{C}$. The blot was washed 3 times with TBST to remove the first antibody. Then a monoclonal antibody reacting with trout IgM (1-14; DeLuca et al. 1983) was added for $1 \mathrm{~h}$ at room temperature on a rocker platform. The second antibody was removed with 3 washes of TBST, followed by the application of a predetermined dilution of horseradish-peroxidase labeled goat anti-mouse IgG and the blot developed with an Amersham ECL kit. The blot was exposed to Kodak X-Omat Blue XB-1 film and developed (Ristow et al. 1993).

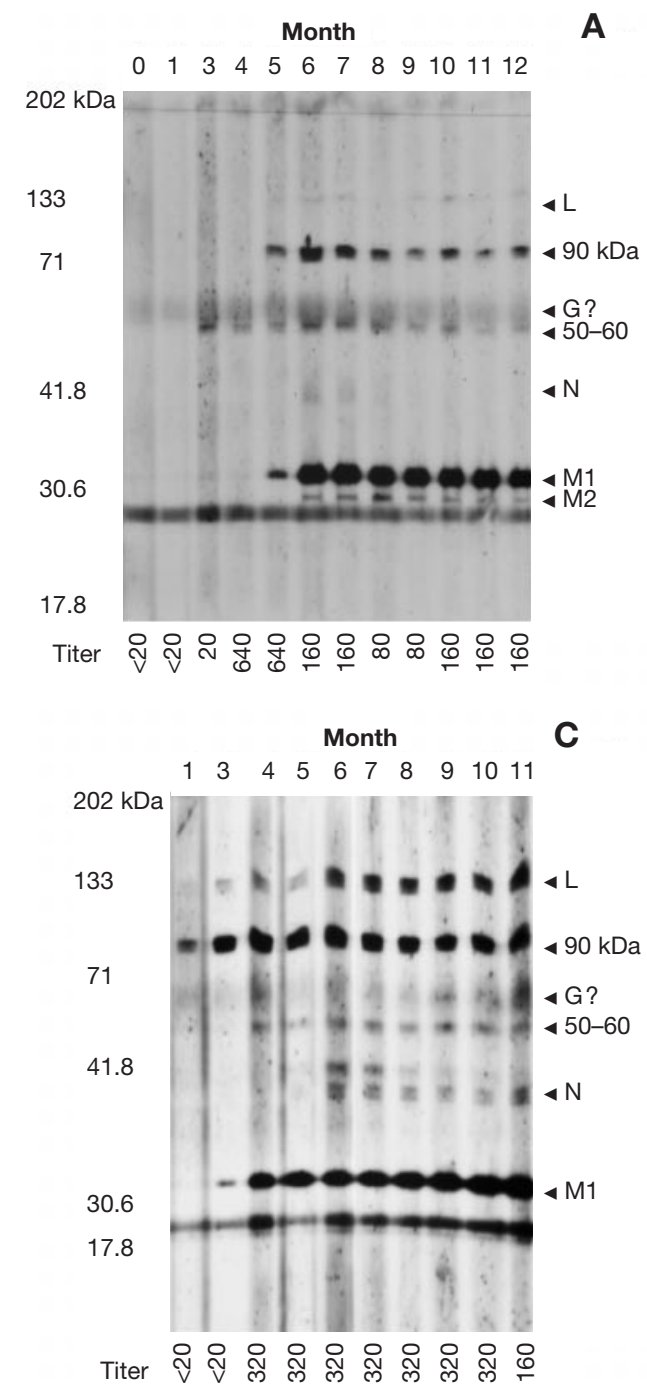

Monoclonal antibody against stress proteins. Monoclonal antibody (MAb) Ab7, against a $90 \mathrm{kDa}$ stress protein found in CHSE-214 cells, was obtained from Jeong-Woo Park (University of Ulsan, Ulsan, Korea) (Lee et al. 1996, Cho et al. 1997). It was used at a dilution of 1:5000 to probe NSL proteins in selected lanes in the western blot procedure.

\section{RESULTS}

\section{Western blot}

Responses of the $16 \mathrm{HC}$ fish (designated A-P) encompassing the first 12 mo of infection varied in the western blots (Fig. 1). All 16 fish responded to the M1 protein of the virus and to a protein at $90 \mathrm{kDa}$. On most

\section{A}

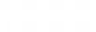




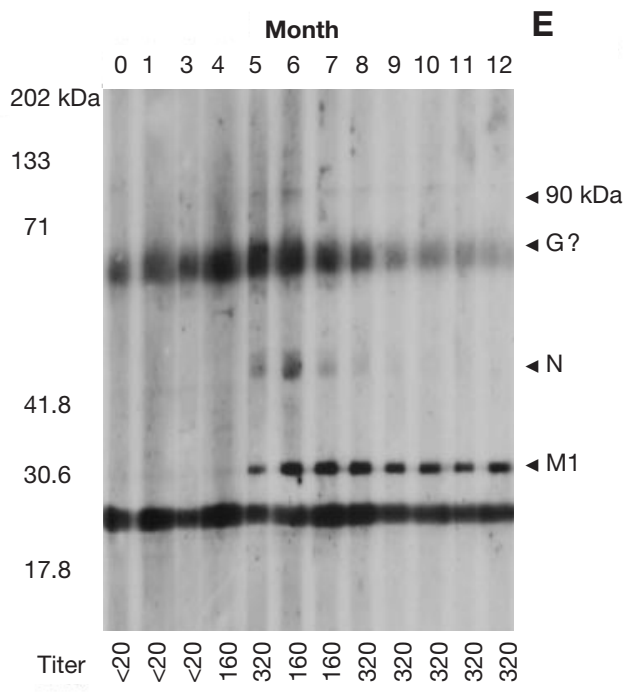

Month

G

$\begin{array}{lllllllllll}0 & 1 & 3 & 4 & 5 & 6 & 7 & 8 & 9 & 10 & 1112\end{array}$

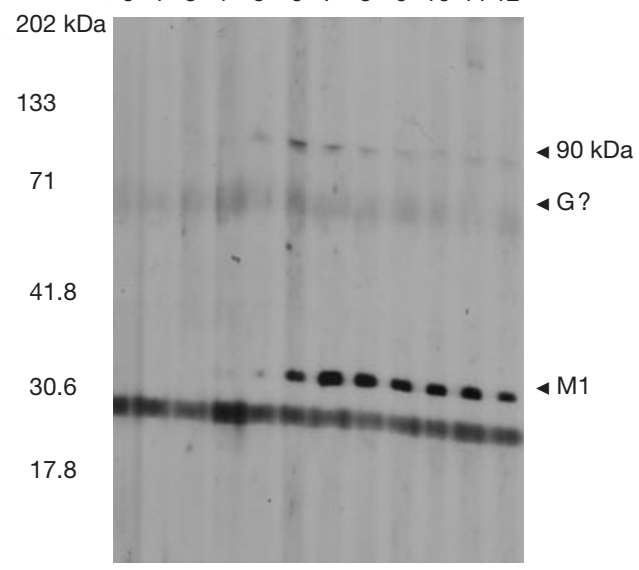

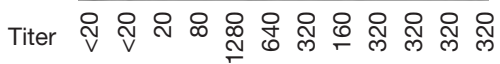
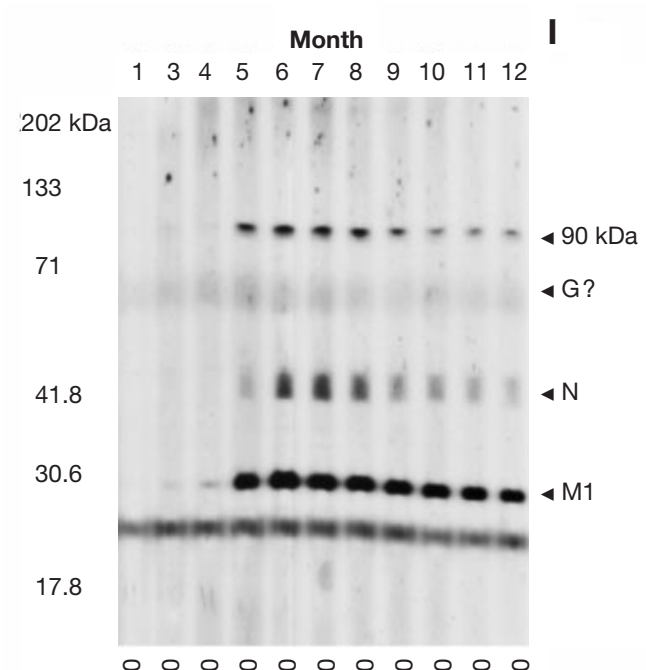

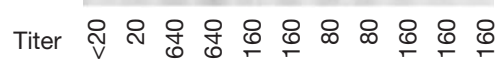
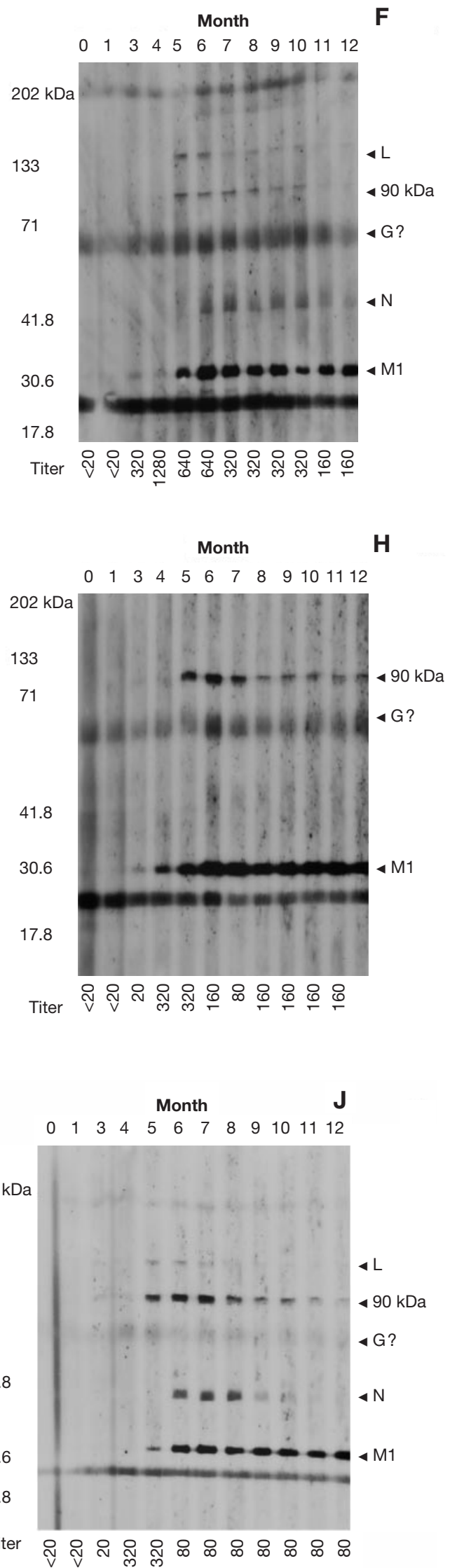

Fig. 1 (continued) 

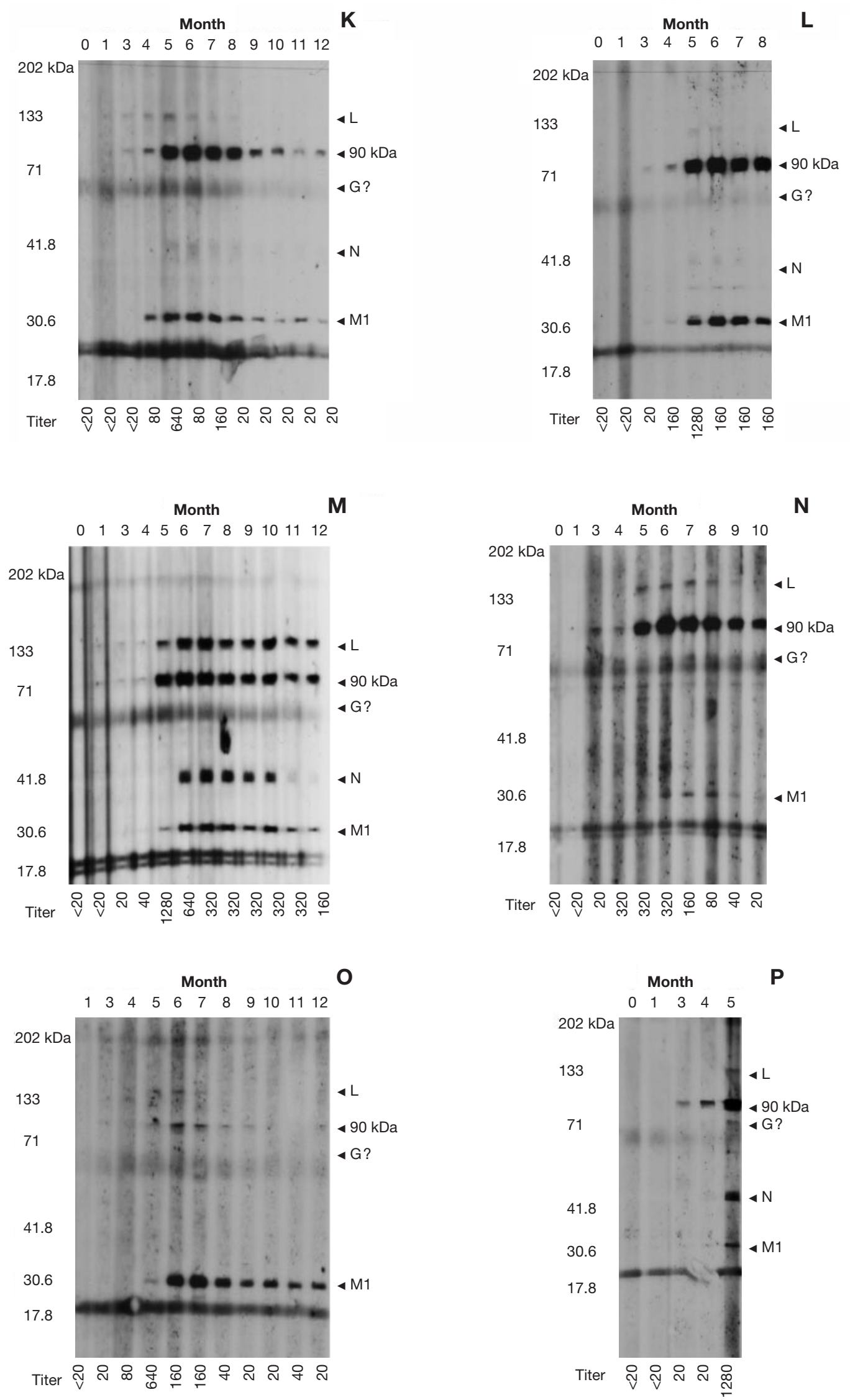

Fig. 1 (continued) 
blots there was a light band in the region of the G protein, but it was also present in non-probed and negative control lanes, thus making the response appear non-specific. Ten of the fish responded to the nucleoprotein N. Four fish gave weak responses to proteins copurifying with the virus at 50 to $60 \mathrm{kDa}$. Only 1 fish responded to M2 (Table 1). When the MAb AB7 and sera from an IHNV immunized trout were used to probe lanes containing the purified NSL virus, both the MAb AB7 and the trout antisera identified a $90 \mathrm{kDa}$ protein associated with the purified NSL virus (Fig. 2).

\section{Complement-dependent serum neutralization tests}

Response patterns in the neutralization test of the 16 HC individuals vaccinated with NSL also varied (Table 2). Peak titers varied from 80 to 1280 . One individual yielded a low overall response (titer $=80$ ) in the test, while 6 individuals achieved a peak titer of 320 . Three reached a titer of 640 and 6 achieved a maximum titer of 1280 . At the end of the first 12 mo of monitoring, $81 \%(13 / 16)$ of the fish had survived and exhibited a median titer of 160 with 5 of these fish still exhibiting a higher titer of 320. At 18 mo $56 \%$ (9/16) of the fish survived and exhibited a median titer of 160 .

\section{DISCUSSION}

Previous results from our laboratories showed that outbred trout surviving several epizootics of IHNV produced a great variety of responses in the western blot to the proteins of the virus (LaPatra et al. 1993. Ristow et al. 1993). Because the HC trout are homozygous clones, we expected that all responses would

Table 1. Cumulative serum response. Sera collected from cloned Hot Creek rainbow trout Oncorhynchus mykiss previously infected with Nan Scott Lake (NSL) IHNV was tested in western blots against the purified NSL antigen. MW: molecular weight. Bold indicates predominant response: all fish responded

\begin{tabular}{|cc|}
\hline MW band & No. responding \\
\hline $133 \mathrm{kDa}(\mathrm{L})$ & 10 \\
$\mathbf{9 0} \mathbf{~ k D a}$ & $\mathbf{1 6}$ \\
$\mathrm{G}(\text { ? })^{\mathrm{a}}$ & 16 \\
$50-60 \mathrm{kDa}$ & 5 \\
$\mathrm{~N}$ & 11 \\
M1 & $\mathbf{1 6}$ \\
M2 & 1 \\
& $\mathrm{n}=16$ \\
apresent in non-probed and (-) control lanes, non-specific \\
response
\end{tabular}

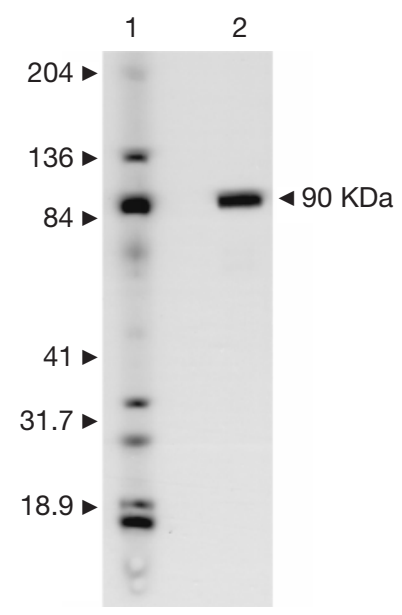

Fig. 2. Western blot analysis of NSL IHNV antigen. A nitrocellulose membrane containing the IHNV proteins was probed with an NSL antiserum from a single fish (lane 1) and monoclonal antibody (MAb) AB7 (lane 2). The $90 \mathrm{kDa}$ protein was shown to be present by both probes

be uniform; however, they were not. Although all of the fish responded to a $90 \mathrm{kDa}$ protein and $\mathrm{M} 1$, there was a somewhat uneven response to the nucleoprotein $\mathrm{N}$ and to M2. Additionally, the kinetics of the neutralization titers varied; and although there was only a nonspecific response to $\mathrm{G}$ appearing in the western blot, most of the trout exhibited strong neutralization titers, indicating the presence of a response to the $\mathrm{G}$ protein (Engelking \& Leong 1989).

Since the primary protective response to IHNV is expected to be against the $G$ protein of the virus (Engelking \& Leong 1989), it seemed unusual that there was such a low or nonspecific response to $G$ in the western blot. In a previous report in which adult trout were immunized with IHNV in combination with Freund's complete adjuvant, the primary responses noted in the western blot were to the G and M1 protein (Mourich \& Leong 1991). The response of our cloned $\mathrm{HC}$ trout to the $\mathrm{G}$ protein in the present experiments may have been primarily to tertiary or conformational epitopes, and these responses may not have been detected on the western blot under the reducing conditions used (LaPatra et al. 1993, Ristow et al. 1993). However, outbred rainbow trout were able to produce antibodies that recognized all the rhabdovirus proteins when blotted under reducing conditions, but this was observed only after repeated stimulations with wildtype virus. Ristow et al. (1993) observed increased immunoblotting reactivity following 5 subsequent exposures to IHNV. It also has been demonstrated that the response of mice to the G protein of IHNV contains a component directed toward the conformational or 3-dimensional epitopes (Huang et al. 1994). The anti- 
Table 2. Complement-dependent neutralization titers for Hot Creek rainbow trout. Fish were intraperitoneally injected with $1 \times 10^{5}$ pfu of IHNV at Month 0 and subsequently injected with $1 \times 10^{7}$ pfu at Month 2 and $2 \times 10^{7}$ pfu at Month 4 , post-infection. Fish were bled monthly for serum. nd: not done; ns: no sample. Bold indicates highest titer achieved

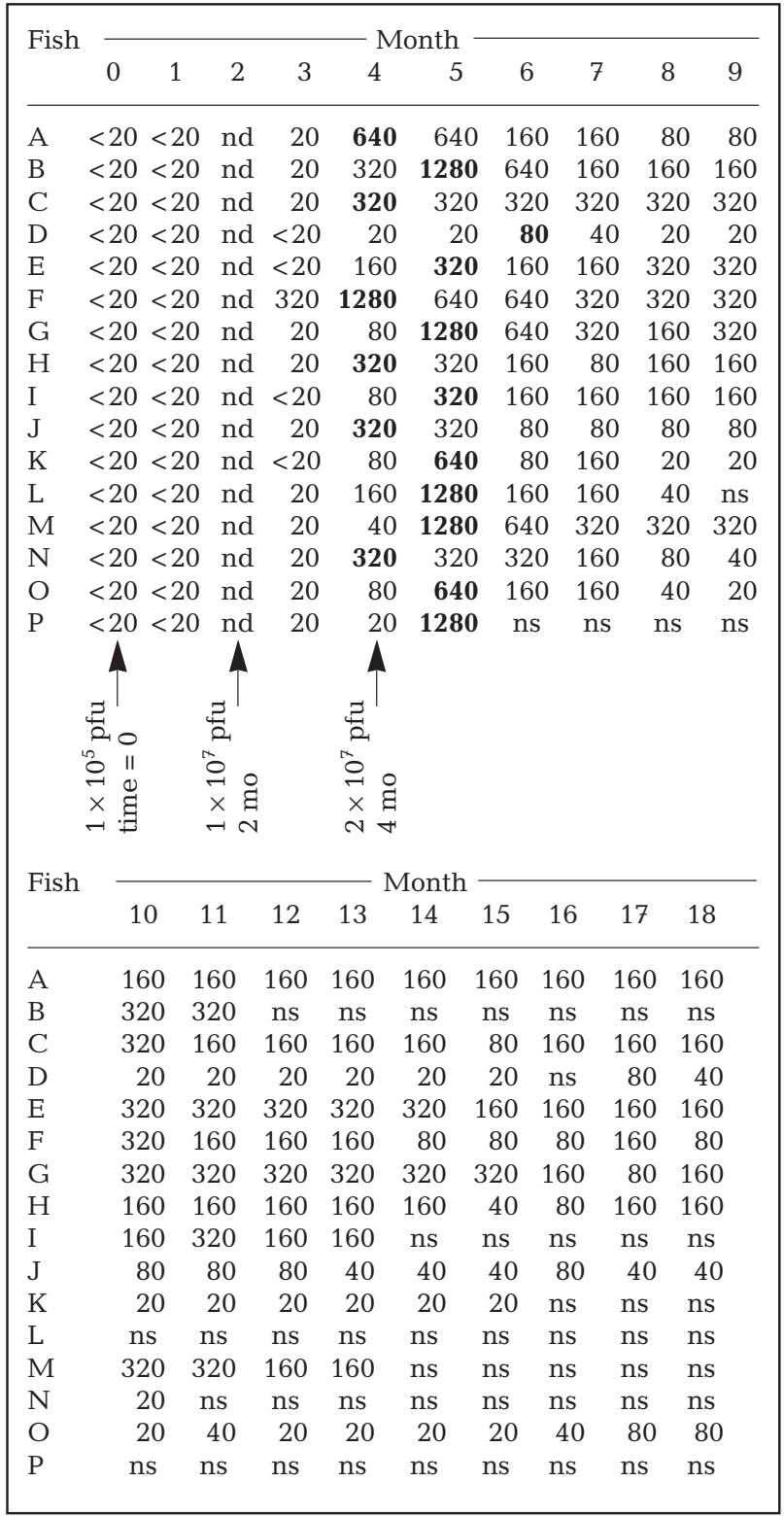

genic sites seen by outbred trout on the linearized G protein have been described by Xu et al. (1991), who probed TrpE-G fusion proteins of the G protein with their sera and then immunized naive trout with the individual fusion proteins as prototype vaccines for IHNV. The fusion protein induced an immuno-protective response in fish.

While it is tempting to speculate that a portion of the neutralizing activity detected in these sera might be due to reaction with the $90 \mathrm{kDa}$ protein or $\mathrm{M} 1$, recent results contributed by Corbeil et al. (1999) and work by Engelking \& Leong (1989) suggest that this is not the case. However, Lee et al. (1996) found that MAb AB7, which identifies the unique $90 \mathrm{kDa}$ stress protein derived from CHSE 214 cells, was by itself able to neutralize a Korean isolate (PRT) of IHNV in vitro. Both MAb AB7 and trout antisera identified the $90 \mathrm{kDa}$ protein of NSL in western blots (Fig. 2) and this protein appeared to be the $90 \mathrm{kDa}$ protein previously described by other investigators (Lee et al. 1996, Cho et al. 1997). The $90 \mathrm{kDa}$ stress protein is not a classical heat shock protein. Lee et al. (1996) also tested 4 other MAbs identifying 4 classical stress proteins including hsp60, hsp70, hsp90 and grp94 and noted that they did not cross-react against the $90 \mathrm{kDa}$ protein present in CHSE-214 cells. They also found that this unique $90 \mathrm{kDa}$ cellular protein was constituitively expressed at low levels in CHSE-214 cells and that its production was augmented when the cells were infected with IHNV or were heat-shocked. The $90 \mathrm{kDa}$ protein is tightly associated with the purified virions of IHNV (Lee et al. 1996) and remains associated with the virion through a number of centrifugations and washings. In fact, it remained so firmly attached that treatment with trypsin was necessary to dissociate it from the virion.

To find other proteins associated with purified rhabdoviruses is not unusual. Investigators have reported that the hsp70 strongly associates with the rabies virion (Sagara \& Kawai 1992) and that the molecular chaperones, BiP and calnexin, are associated with purified vesicular stomatitis virus (VSV) (Hammond \& Helenius 1994, Hammond et al. 1994). The molecular chaperone BiP is bound early in the molecular folding of the VSV G protein, whereas calnexin is bound to more mature folded molecules. Not only are chaperones and heat shock proteins found with purified rhabdoviruses, but they are also associated with other viruses: canine distemper (Oglesbee et al. 1990), adenovirus (Macejak \& Luftig 1991), sindbis virus (Mulvey \& Brown 1995) and vaccinia virus (Jindal \& Young 1992). Sagara et al. (1995) identified the cellular actin-binding EzrinRadixin-moesin (ERM) family of proteins incorporated into the rabies virion. The ERM family are members of the actin binding proteins thought to be involved in the anchoring or connecting of the actin filaments to the plasma membrane. The ERM bands were found to comprise 0.5 to $0.7 \%$ of the protein of the rabies virus preparations.

It was interesting that all of the sera from the different time points from the immunized Hot Creek clones reacted in western blots with both the M1 and the $90 \mathrm{kDa}$ protein exactly as did the outbred trout described in the experiments of Lee et al. (1996). In the western blot the responses to both of these proteins 
predominated over the response to the $\mathrm{G}$ protein. It is tempting to speculate that if the neutralizing responses noted in our complement-dependent neutralization assays were to $G$, they must have been directed at the tertiary epitopes because the responses to $\mathrm{G}$ on the western blot were nonspecific. Since the $90 \mathrm{kDa}$ protein is a CHSE-214 derived protein and those cells originated from Chinook salmon embryos (Lannan et al. 1984), it is possible that the $90 \mathrm{kDa}$ protein is quite immunogenic to the $\mathrm{HC}$ rainbow trout.

Analysis of the monthly western blot reactions with the IHNV neutralization titers illustrated the strong correlation between the 2 assays. The strongest protein reactions in the western blots are generally observed when the highest neutralization titer is detected or with serum obtained the following month. Additionally, the strength of the protein reactions begins to fade over time as neutralization titers decrease. Although this would be anticipated, this observation further strengthens the correlation of the 2 assays and helps validate hypotheses postulated to explain the results of the study. It is also interesting to note that the $\mathrm{M} 1$ and $90 \mathrm{kDa}$ proteins are always the first reaction noted on the western blots, also occurring occasionally with a protein found at $133 \mathrm{kDa}$, presumably the $\mathrm{L}$ protein (Fig. 1D,M).

Another interesting result in these experiments was the prolonged humoral response of the clones to the virus as demonstrated by the serum neutralization activity. Additionally, the response to M1 continued for $18 \mathrm{mo}$ and the response to the $90 \mathrm{kDa}$ protein remained visible in the western blot till the end of the observation period in 3 of the 9 remaining fish. At 18 mo the 9 remaining fish had a median titer of 160 . Hedrick (1998) noted that the outcome of an infection is a matter of balance between environmental factors, the status of the host and the pathogen. He emphasized that the temperature can play a critical role in the outcome of an infection particularly by viral hemorrhagic septicemia virus (VHSV), another rhabdovirus infecting trout. Jørgensen (1982) had previously observed that at lower temperatures the VHSV was able to persist for a longer time and at higher levels, giving the fish the time to respond at a high level and to have the response persist for a greater time. Thus, since our fish were maintained at a relatively low temperature $\left(12^{\circ} \mathrm{C}\right)$, it is tempting to speculate that the reason we were seeing prolonged serum neutralization titers is that our homozygous fish were in the same slowed response mode as the fish described by Jørgensen.

Alternatively, the prolonged presence of relatively high IHNV neutralization titers could have resulted from the low water temperature and/or the vaccination regime. At the first vaccination, each fish was immu- nized with a low dose $\left(1 \times 10^{5} \mathrm{pfu}\right)$ of the attenuated IHNV strain; after $1 \mathrm{mo}$, the fish were bled and no neutralization titers were detected. Two months after the first vaccination, a second injection of virus was given at a significantly higher dose $\left(1 \times 10^{7} \mathrm{pfu}\right)$ and the trout were bled 1 mo later and tested for neutralization activity. Although the titers were generally low, $75 \%(12 / 16)$ of the fish had detectable neutralization activity. One month later (4 mo after the first vaccination) the fish were injected a third time with a high dose of virus $\left(2 \times 10^{7} \mathrm{pfu}\right)$. Neutralization titers detected in every vaccinated fish were dramatically higher at 4 and 5 mo after the first vaccination or 2 and 3 mo after the second vaccination. The titers began to drop at Month 6 but were maintained at a relatively high level throughout the duration of the 18 mo experiment. At the end of the study, all the remaining fish had detectable neutralization activity with a mean titer of 133. At $15^{\circ} \mathrm{C}$ in a comparable sized, outbred strain of rainbow trout, a single dose (approximately $10^{7} \mathrm{pfu}$ ) of attenuated virus generally produces peak titers at $6 \mathrm{wk}$ post-vaccination. By $30 \mathrm{wk}$ post-vaccination neutralization titers decrease to negligible levels (authors' unpubl. obs.). Whether repeated stimulation with rhabdovirus antigens to obtain long duration neutralization activity reflects an adaptive immune response or affinity maturation described in mammals appears uncertain. It has been suggested that fish may possess a more simple secondary immune response mechanism characterized by a more differentiated response after repeated exposures to a specific antigen (Kaattari \& Piganelli 1997). The results of other studies also indicate that memory in rainbow trout may be due to a simple expansion of the antigen specific precursor pool without the many qualitative changes in antibody or B cell function associated with the expression of memory in mammals (Arkoosh \& Kaattari 1991). This could account for the long duration in virus neutralization activity that was detected in these fish after multiple injections of high concentration of live virus. Alternatively, the persistence of the antibody response might be explained by the persistence of the virus within the fish themselves or in the system in which they were contained.

In the future, it will be interesting to examine more closely the serological responses of various clones of rainbow trout to the G protein of IHNV, particularly the responses to the tertiary epitopes of this important immunogen.

Acknowledgements. This work was supported in part by USDA-NRI grant number 95-37204-2434 and grants from the USDA Regional Aquaculture Consortium 98-38500-6001 and 99-38500-7507. 


\section{LITERATURE CITED}

Amend DF (1976) Prevention and control of viral diseases of salmonids. J Fish Res Board Can 33:1059-1066

Anderson ED, Mourich DV, Leong JC (1996a) Genetic immunization of rainbow trout (Oncorhynchus mykiss) against infectious hematopoietic necrosis virus. Mol Mar Biol Biotech 5:114-122

Anderson ED, Mourich DV, Leong JC (1996b) Gene expression in rainbow trout (Oncorhynchus mykiss) following intramuscular injection of DNA. Mol Mar Biol Biotech 5:105-113

Arkoosh MR, Kaattari SL (1991) Development of immunological memory in rainbow trout (Oncorhynchus mykiss). I. An immunochemical and cellular analysis of the B cell response. Dev Comp Immunol 15:279-293

Cho WJ, Cha SJ, Do JW, Choi JY, Lee JY, Jeong CS, Cho KJ, Choi WS, Kang HS, Kim HD, Park JW (1997) A novel 90-kDa stress protein induced in fish cells by fish rhabdovirus infection. Biochem Biophys Res Commun 233: 316-319

Corbeil S, LaPatra SE, Anderson ED, Jones J, Vincent B, Hsu YL, Kurath G (1999) Evaluation of the protective immunogenicity of the N, P, M. NV and G proteins of infectious hematopoietic necrosis virus in rainbow trout Oncorhynchus mykiss using DNA vaccines. Dis Aquat Org 39:29-36

DeLuca D, Wilson M, Warr GW (1983) Lymphocyte heterogeneity in the trout, Salmo gairdneri, defined with monoclonal antibodies to IgM. Eur J Immunol 13:546-551

Emmenegger E, Landolt M, LaPatra S, Winton J (1997) Immunogenicity of synthetic peptides representing antigenic determinants on the infectious hematopoietic necrosis virus glycoprotein. Dis Aquat Org 28:175-184

Engelking HM, Leong JC (1989) The glycoprotein of infectious hematopoietic necrosis virus elicits neutralizing antibody and protective responses. Virus Res 13:213-230

Engelking HM, Harry JB, Leong JC (1991) Comparison of representative strains of infectious hematopoietic necrosis virus by serological neutralization and cross-protection assays. Appl Environ Microbiol 57:1372-1378

Fijan N, Salimanovic D, Bearzotti M, Muzinic D, Zwillenberg LO, Chilmonczyk S, Vautherot JF, de Kinkelin P (1983) Some properties of the Epithelioma papulosum cyprini (EPC) cell line from carp Cyprinus carpio. Ann Inst Pasteur Virol 134E:207-220

Hammond C, Helenius A (1994) Folding of VSV G protein: sequential interaction with BiP and calnexin. Science 266: $456-458$

Hammond C, Braakman I, Helenius A (1994) Role of N-linked oligosaccharide recognition, glucose trimming and calnexin in glycoprotein folding and quality control. Proc Natl Acad Sci USA 91:913-917

Hedrick RP (1998) Relationship of the host pathogen and environment: implications for diseases of cultured and wild fish populations. J Aquat Anim Health 10:107-111

Huang C, Chien MS, Landolt M, Winton J (1994) Characterization of the infectious hematopoietic necrosis virus glycoprotein using neutralizing monoclonal antibodies. Dis Aquat Org 18:29-35

Jindal S, Young RA (1992) Vaccinia virus induces a stress response that leads to association of hsp70 with viral proteins. J Virol 66:5357-5362

Jørgensen PEV (1982) Egtved virus: temperature dependent immune response of trout in infections with low virulence virus. J Fish Dis 5:47-55

Kaattari SL, Piganelli JD (1997) Immunization with bacterial antigens: bacterial kidney disease. Dev Biol Stand 90 145-152

Lannan CN, Winton JR, Fryer JL (1984) Fish cell lines: establishment and characterization of nine cell lines from salmonids. In Vitro 20:671-676

LaPatra SE (1996) The use of serological techniques for virus surveillance and certification of finfish. Annu Rev Fish Dis 6:15-28

LaPatra SE, Lauda KA, Morton AW (1991) Antigenic and virulence comparison of eight isolates of infectious hematopoietic necrosis virus from the Hagerman Valley, Idaho, USA. In: Fryer JL (ed) Proceedings of the second international symposium on viruses of lower vertebrates. Oregon State University Press, Corvallis, p 125-129

LaPatra SE, Turner T, Lauda KA, Jones GR, Walker S (1993) Characterization of the humoral response of rainbow trout to infectious hematopoietic necrosis. J Aquat Anim Health 5:165-171

Lee JY, Cho WJ, Do JW, Kin HJ, Park JW, Park MA, Sohn SG, Jeong G, Hah YC (1996) Monoclonal antibodies raised against infectious hematopoietic necrosis virus (IHNV) G protein and a cellular $90 \mathrm{kDa}$ protein neutralize IHNV infection in vitro. J Gen Virol 77:1731-1737

Leong JC, Hsu YL, Engelking HM, Mulcahy D (1981) Strains of infectious hematopoietic necrosis (IHN) virus may be identified by structural protein differences. Dev Biol Stand 49:43-55

Leong JC, Fryer JL, Winton JR (1988) Vaccination against infectious hematopoietic necrosis virus. In: Ellis AE (ed) Fish vaccination. Academic Press, New York, p 193-203

Macejak DG, Luftig RB (1991) Association of hsp 70 with the adenovirus type 5 fiber protein in infected HEp-2 cells. Virology 180:120-125

Mourich DV, Leong JC (1991) Mapping of the immunogenic regions of the IHNV glycoprotein in rainbow trout and mice. In: Fryer JL (ed) Proceedings of the second international symposium on viruses of lower vertebrates. Oregon State University Press, Corvallis, p 93-100

Mulvey M, Brown DT (1995) Involvement of the molecular chaperone BiP in maturation of Sindbis virus envelope glycoproteins. J Virol 69:1621-1627

Oglesbee M, Ringler S, Krakowka S (1990) Interaction of canine distemper virus nucleocapsid variants with $70 \mathrm{~K}$ heat-shock proteins. J Gen Virol 71:1585-1590

Parsons JE, Thorgaard GH (1985) Production of androgenetic diploid rainbow trout. J Hered 76:177-181

Quillet E, Garcia P, Guyomard R (1991) Analysis of the production of all homozygous lines of rainbow trout by gynogenesis. J Exp Zool 257:815-819

Ristow SS, de Avila J, LaPatra SE, Lauda K (1993) Detection and characterization of rainbow trout antibody against infectious hematopoietic necrosis virus. Dis Aquat Org 15: 109-114

Ristow SS, Grabowski LD, Wheeler PA, Prieur DJ, Thorgaard GH (1995) Arlee line of rainbow trout (Oncorhynchus mykiss) exhibits a low level of nonspecific cytotoxic cell activity. Dev Comp Immunol 19:497-505

Ristow SS, Grabowski LD, Ostberg C, Robison B, Thorgaard GH (1998) Development of long-term cell lines from homozygous clones of rainbow trout. J Aquat Anim Health 10:75-82

Ristow SS, Grabowski LD, Thompson SM, Warr GW, Kaattari SL, de Avila JM, Thorgaard GH (1999) Coding sequences of the MHC II $\beta$ chain of homozygous rainbow trout (Oncorhynchus mykiss). Dev Comp Immunol 23:51-60

Sagara J, Kawai A (1992) Identification of heat shock protein 70 in the rabies virion. Virology 190:845-848 
Sagara J, Tsukita S, Yonemura S, Tsukita S, Kawai A (1995) Cellular actin-binding ezrin-radixin-moesin (ERM) family proteins are incorporated into the rabies virion and closely associated with viral envelope proteins in the cell. Virology 206:485-494

Scheerer PD, Thorgaard GH, Allendorf FW, Knudsen KL (1986) Androgenetic rainbow trout produced from inbred and outbred sperm sources show similar survival. Aquaculture 57:289-298

Scheerer PD, Thorgaard GH, Allendorf FW (1991) Genetic ana-

Editorial responsibility: Jo-Ann Leong,

Corvallis, Oregon, USA lysis of androgenetic rainbow trout. J Exp Zool 260:382-390

$\mathrm{Xu}$ L, Mourich DV, Engelking HM, Ristow S, Arnzen J, Leong JC (1991) Epitope mapping and characterization of infectious hematopoietic necrosis virus glycoprotein, using fusion proteins synthesized in Escherichia coli. J Virol 65: $1611-1615$

Young WP, Wheeler PA, Fields RD, Thorgaard GH (1996) DNA fingerprinting confirms the isogenecity of androgenetically-derived rainbow trout lines. J Hered 87: $77-81$

Submitted: March 1, 2000; Accepted: June 1, 2000

Proofs received from author(s): September 12, 2000 